\title{
Through Education and Work Experience toward Professional Competence - A Phenomenographic Study on Some Finnish Nurses’ and Midwives’ Perceptions
}

\author{
Airi Paloste \\ Health Care and Social Services, Kemi-Tornio University of Applied Sciences \\ P.O. Box 506, 94101 Kemi, Finland \\ Tel: 358-40-741-2905Ｅ-mail: airi.paloste@tokem.fi
}

\begin{abstract}
Satu Uusiautti
Faculty of Education, University of Lapland

(May-Sep) Lepolantie 29, 01830 Lepsämä, Finland

(Oct-Apr) 2430 SE 8th Avenue, Cape Coral, 33990, FL, USA
\end{abstract}

Tel : 358-50-355-1280 / 1-239-789-5562 E-mail : satu@uusiautti.fi

Kaarina Määttä (Corresponding author)

Faculty of Education, University of Lapland

P.O. Box 122, 96101 Rovaniemi, Finland

Tel: 358-400-696-480Ｅ-mail: Kaarina.Maatta@ulapland.fi

Received: August 5, 2011 Accepted: August 15, $2011 \quad$ Published: December 1, 2011

doi:10.5296/jse.v1i1.841ＵRL: http://dx.doi.org/10.5296/jse.v1i1.841

\begin{abstract}
The purpose of this article is to describe graduated nurses and midwives' ( $\mathrm{N}=39)$ opinions on their professional competence that they have acquired from nursing education at the university of applied sciences in Finland. The data was collected in three phases through inquiries and theme interviews. The research approach was phenomenographic. The results
\end{abstract}




\section{Macrothink

show how working nurses' and midwives' opinions on their professional competences acquired from education could be divided into three categories: 1) strengthening the professional identity, 2) developing the functional professional qualifications, and 3) developing the outer functional qualifications. They also expressed their opinions on how to develop the contents of education, teachers' instruction, and connections with working life. We created a model of the development of professional competence in nursing to help developing nursing education at the universities of applied sciences, curriculum work, and cooperation with working life.

Keywords: Professional Competence, Nursing Education, University of Applied Sciences 


\section{Introduction}

Prospective societal and cultural changes and internationalization demand readiness to flexible and multiprofessional work, entrepreneurship, continuous self-development, knowing the time of the day, and critical thinking from health care professionals. Willingness to constant professional development has become the core of professional competence (Eustace, 2001; Khomeiran et al., 2006). The concept of professional competence has many dimensions. Ellström (1994) distinguishes the following types of competence from each other: actual competence, competence required at work, exploited competence, formal competence, and competence determined from outside.

Formal and actual competence may differ (While, 1994). Indeed, when evaluating professional competence and readiness, the focus should be on the evaluation of actual competence in concrete situations and not just on educational criteria. Similarly, exploited competence may be the same than actual competence but not necessarily as there can be imbalance between exploited competence and the qualification requirements of the work (see Watson, Stimpson, Topping, \& Porock, 2002). Nursing education is supposed to give prospective health care professionals qualifications to nursing in various task areas but official qualification requirements and vocational proficiency may be something that cannot be produced by education (Aggleton, Allen, \& Montgomery, 1987; Ashworth \& Morrison, 1991). In this research, professional competence means an individual's skill and will to apply his/her versatile skills, attitudes, cognitive readiness and his/her own personality in the practical work so that the work outcome is as high-quality as possible.

Plenty of follow-up studies on the vocational education of nursing sciences and evaluations of the quality of professional competence have been carried out across the world, for example, in Australia (Andre \& Heartfield, 2007; Gonzi, 1994), England (Girot, 2000; Bartlett et al., 2000), Israel (Medoff-Cooper \& Dekeyser, 1998), Malaysia (Chiu \& Hong, 2005), Scotland (Butterworth, 1997), Sweden (Lundblad, Byrne, \& Hellstrom, 2001), and Taiwan (Tzeng \& Ketefian, 2003). The most interest has focused on students' perceptions exactly. Longitudinal studies about graduates' opinions have been made as well (Elmcrona \& Winroth, 1997; Thompson \& Rebeschi, 1999). However, Finnish health care professionals' perceptions on their professional competence have not been studied much. This research contributes to this discussion by presenting nurses' own perceptions on their competence and by introducing a model of the competence in nursing field.

In this research, we report Finnish nurses' and midwives' opinions on their professional competence and how it developed in nursing education. The research focused on the participants' perceptions that are analyzed through the formation of individuals' perceptions. Then, the relationship that the perception forms between an individual and his/her surrounding world is analyzed. The research is qualitative with a phenomenographic approach and the aim was to focus on describing the participants' opinions. (Marton, 1994; 
Syrjälä, Ahonen, Syrjäläinen, \& Saari, 1994.)

\section{Professional Competence as the Goal of Nursing Education}

\subsection{What is Professional Competence?}

The concept of professional competence is close to the concept of potential (Streumer, 1993). It means an individual's potential capacity in relation to a certain/determined task, situation, or context (Ellström, 1994; Westerholm, 2007). Professional competence refers to an individual's subjective perception on his/her possibilities and abilities to act according to the goals and facility to affect his/her environment (Ruohotie, 1993). Furthermore, professional competence means how well tasks are performed and organized and how they are developed in order to achieve the goal (Evers, Rush, \& Berdrow, 1998). Professional competence consists of ability to integrate information and learned skills into practice according to expectations. Professional competence also manifests an individual's attitude and behavior in certain work situations (Katz, 1998). Competence is always competence to do something. It is seen as an inevitable prerequisite for successful or at least satisfactory professional performance. (Munch \& Jakobsen, 2005.) Besides being a factor of health, work environment, and work community, professional competence affects an individual's working capacity (Bergström et al., 1997). Proficiency and working capacity are interconnected so that the areas of working capacity that are related to health, work community, and working environment form the prerequisite of using one's proficiency.

Professional competence is a dynamic concept. It can be used, developed, and changed with time (Clafin, 1997). The content of professional competence changes constantly along with new jobs, changing the division and organization of labor, technology and new information. It forms one phase of professional development from a novice into an expert. Professional competence develops the best in a learning process where people participate in developing their own work, in other words, are developers of the work and not just executors (Drexel, 2003). One crucial part of professional competence is a strong knowledge base. It covers general, profession-related and -specific information. However, a strong and wide-ranging knowledge base is not solely enough but one has to be familiar with the newest information, applications, and achievements of one's own and neighboring fields. In addition, one should look for applications for the most recent knowledge and bring out one's expertise so that it becomes respected among colleagues and other experts. (Ruohotie, 1993.) Furthermore, one needs skill to combine relevant information and ability to integrate information into the context as well as be able to adopt new information quickly (Eraut, 1998).

\subsection{General Work-Life Readiness and Qualifications}

Versatile skills form an important part of professional competence (Evers et al., 1998; Ruohotie, 1993). Employers hope that employees had learning-to-learn skills, communication skills such as listening, and the skills of verbal and written communication, as well as ICT skills. Employees are expected to express adaptability, creative thinking, and problem-solving skills. Furthermore, employers wish that employees were able to personal leadership that includes self-respect, motivation, goal- and career-orientation, as well as to group work 
including cooperation, negotiation, and team-work. Ideal employees have also influence on the organization and have leadership and administrative skills. (Carnevale, Gainer, \& Meltzer, 1990.)

Organizing and coordinating skills are also needed at work (Evers \& Rush, 1996). Organizing skills are needed both for organizing one's own work and the functioning of the work community as well. Also time-management skills and prioritizing skills, which mean the ability to know how to use the working time efficiently and in which sequence the tasks should be done, can be seen as organizing skills. (Evers et al., 1998; Wolgin, 1998.)

Interaction, cooperation, and group work skills are needed in human relationship work and service trades but the ability to work autonomously is crucial as well (Wolgin, 1998; Evers et al., 1998). Today, the role of independent work is emphasized more than before because personnel have been cut off in several organizations. In human relationship work and service trades such as nursing, the ability to listen and communicate as well as human relationship skills and willingness to be of service are needed. (Wolgin, 1998; Evers et al., 1998.)

Personality is one part of professional competence. Employees are expected to have initiative, high work motivation and work ethic - and strong commitment and a positive attitude to work and their profession as well. They are supposed to accept challenging tasks and take responsible to their own work. (Evers et al., 1998; Eteläpelto, 1992; Wolgin, 1998.)

Professional competence can also be considered covering the skills gathered from experience. According to Kautto-Koivula (1993), an employee learns both from success and failures and by observing various events, treatment situations and happenings. Keen (1991), on the other hand, highlights the meaning of professional contacts with colleagues, patients, and interest groups for professional competence. Tolerating and engaging in constant changes in working life become easier if employees are ready to cope with the changes and willing to flexible working. (Evers et al., 1998; Eteläpelto, 1992; see also Uusiautti \& Määttä, 2011.)

\subsection{Professional Competence in Nursing}

Within the nursing education, the concepts of professional competence, qualification, and professional skills are used quite diversely. Partly the concepts are used for compensating each other or they are even regarded as synonyms (Dozier, 1998). According to Ellström (1994), the concepts are related to each other and they share a common core but each of them also has its own meaning.

Qualification relates to professional competence so that working life produces those demands that are required of professional nurses. Working and developing one's work require certain kind of expertise. These fields of know-how or required proficiency are called qualification requirements. Thus, qualification refers to that recognized proficiency with which an employee can meet the challenge of the work or employer. Competence means that professional proficiency which is used for meeting the qualification requirements of the work. (Brzytwa, Copeland, \& Hewson, 2000.)

Traditionally, the difference between qualification and competence has been that one can be 
competent for doing something even if one does not have an official degree or is not qualified some other way. In extreme cases, an employee may be technically qualified for the job (e.g. graduated as a nurse at a university of applied sciences) but is not able to work as nurse in a way the employer expects (Watkins, 2000). Considering the above-mentioned situation, EU commission (1996) has suggested that it would be necessary to move from qualification thinking toward competence thinking. In this research, we lean on the competence perspective and use the concept of competence systematically.

Nurses' and midwives' work necessitates the theoretical mastery of the work and cognizance of the knowledge base of nursing. It forms the foundation to the practical work and its content. Nursing consists of both skills and science and working as a nurse requires understanding and applying relevant information and skills. Work necessitates constant renewal, critical thinking, questioning, deliberating new ways of action and thinking, adaptation and application. Weidner (1995) highlights the ability to plan. Certainly, a nurse needs manual and technological skills to perform various treatments safely and quickly (Raven, 1995). Nurses need interaction skills and ethical thinking and responsibility (Weidner, 1995). Additionally, several demands are placed on nurses' personality, such as conscientiousness, patience, activeness, motivation to help people, efficiency, moral courage, and maturity.

Often people think that only supervisors need administrative and management skills but every nurse needs those skills as well (Evers et al., 1998). In addition to technical skills such as ability to use various devices and machines and manual skills such as dexterity (Sinclair \& Gardner, 1999), decision-making and problem-solving skills (Evers et al., 1998; Watkins, 2000; Zhang, Luk, Authur, \& Wong, 2001) are needed in nursing professions.

Planning, documenting, evaluation, and development are emphasized in nursing increasingly (Kautto-Koivula, 1993; Wolgin, 1998). Planning and evaluating one’s own work may take place, for example, with the supervisor. Feedback given by the supervisor and other coworkers has to be used for developing oneself. Functional informing requires good verbal and written informing skills both of supervisors and employees. (Evers et al., 1998.) Nowadays, information technology such as email and other electric communication systems are broadly used in health care and employees have to be able to use it (Nginin, Simms, \& Erbin-Roesemann, 1993). Common language is important in informing and becoming understood: indeed, language proficiency is emphasized in today's nursing as an increasing amount of customers are immigrants - which also demands cultural competence from nurses (Campinha-Bacote, 2002: Dreher \& Macnaughton, 2002; Giger et al., 2007).

Mentoring is an important skill in nursing because in many situations, nurses are expected to be able to guide and instruct their colleagues and customers. It has been stated that more attention should be paid on mentoring as the need for it has increased (Byrne \& Keefe, 2002; Lorenz, 1986). Nurses use mentoring skills as a natural part of their work (Lorenz \& Pichert, 1989; Stetson et al., 1992).

The goal of the higher vocational diploma in nursing is such professional competence that prepares one as a professional who can work in social and health care as well as national and 
international tasks and as an expert of one's own special field. Proficiency may be seen as know-how, skills, knowledge, functions, and operational processes that the wide professional competence consists of and as the mastery of certain cognitive and scientific themes needed at work. The professional competence that is produced by nursing education must include, for example, the following characteristics of expertise: the theoretical mastery of the work, multidisciplinarity, expertise, manual skills, responsibility, autonomy, collegiality, leadership, personality, intuitivism, situational sensitivity, empathy, ethicality, continuous self-development, learning, and learnedness. (Baillie, 1999; Jaroma, 2000.)

\section{Research Problems}

The purpose of the research is to describe nurses' opinions on their professional competence. The participants had graduated in nursing at the Kemi-Tornio University of Applied Sciences in northern Finland in 1995. The following research questions were set on the research:

1. What kind of opinions do the graduates have on their professional competence in nursing?

2. How would the graduates develop their education in order to attain better competence?

In addition, our purpose is to draw an overall picture on what kind of professional competence could be the goal of nursing education and to create a model of the development of professional competence in nursing.

\section{Data, Analysis, and Methods}

The research data was collected in three different phases between 1995 and 2003. In the first phase, inquiry was made among the nurse and midwife students who graduated from the Kemi-Tornio University of Applied Sciences $(\mathrm{N}=39)$. The students were mostly women: only one of the participants was a man. Over half (59\%) of the students were aged between 22 and 25, 28,5 \% were 22-25 years old and 12,8 \% were 34-48 years old. The data for the second phase of the research was collected in November 1996 and March 1997 through interviews: four nurses and two midwives who had already participated in the previous phase of the research were interviewed concerning their experiences on working life. In the third phase of the research, the same persons were interviewed again.

The research is qualitative with a phenomenographic approach. In this kind of research, the purpose is to reach participants' experiential variations in the perceptions through which they experience, understand, and become aware of the phenomena of the surrounding world. (Marton \& Booth, 1997.) Järvinen (1985) describes this interest as a contemplation of experienced and lived life.

The data analysis started from dissecting the entity to "find solutions" (Marton \& Booth, 1997). The open-ended questions in the questionnaire and the interview data were analyzed through inductive content analysis. The analysis process progressed along with the data collection so that the questionnaire was analyzed the first. At the time of conducting the interviews that focused on the experiences on working life, the results of the graduation phase were ready. The first and the second interview data were analyzed simultaneously. 
The interview data comprised altogether 100 pages of text as a transcript varying from eight to eleven pages per interview. After that the answers were encoded by the student groups and numbers and the same code was used with the interviewees as well. In the results section, we refer to the students with abbreviations $\mathrm{N}$ (nurse) and $\mathrm{M}$ (midwife).

In data analysis, the participants' original expressions were categorized according to their meanings. The categories were formed inductively but were supported by previous studies as well. The purpose was to analyze the research data and make the further analysis easier. In the second and third phases of the data analysis, categorization units and sub-categories were created from the original expressions. The aim was to find out the core contents of each unit and name the sub-themes that emerged. In the fourth phase, wider categories were derived from the sub-categories by reflecting the contentual connections between the sub-categories. Content analysis has to be objective and each step has to be taken in order to get an answer to pre-set research questions. (Tuomi \& Sarajärvi, 2002; Tashakkori \& Teddlie, 2003.) The researcher cannot change the aims of the research in the middle of categorization. As the data was relatively small, the categorization was performed twice to ensure the reliability of the categorization.

\section{Research Results}

\subsection{Nurses’ and Midwives’ Professional Competence}

The research results show the professional competence provided by nursing education appeared as versatile vocational proficiency. We categorized the produced professional competence into three categories: 1) strengthening the professional identity, 2) developing the functional professional qualifications, and 3) developing the outer functional qualifications.

\subsubsection{Education strengthened nurses’ professional identity}

Nurses' professional knowledge was a significant result of nursing education and appeared in a variety of ways. One central feature that reflected in professional growth was the appreciation of one's own occupation.

“During the first years, I learned to appreciate this job.” (N 23)

Nurse's role, position, and job description strengthened leading to higher motivation and self-direction:

"My motivation increased all the time as the studies advanced." (M 5)

Students found the personal meaning of education as quite wide-ranging: they considered essential for example the increase in responsibility, the emergence of new possibilities, and finding a profession in the society. Nursing education was also experienced as a personal time of growth and therefore, was connected with the students' own personal development:

"It has opened my eyes to see this world in a wider way and its going." (N 34)

Those nurses and midwives who had worked for a while associated the professional 
competence acquired through education with vocational proficiency and operational qualifications that we categorized in inner and outer qualifications. Inner qualifications consisted of personal characteristics, ethicality/responsibility, and operational preparedness in nursing. Outer operational qualifications were technological skills, manual skills, tacit knowledge/skills, and theoretical knowledge.

\subsubsection{Education developed nurses’ inner qualifications}

Qualifications that related to thinking and initiative or self-direction, self-confidence, the development of one's own personality, and creative, were considered as personal qualifications.

“And that thing, what was rooted in us well, was the [idea of a] nurse who asks". (M 6)

Reflectivity and one's own thinking had developed during education. Students learned to evaluate, observe, and question their own professional competence (Angel, Duffey, \& Belyea, 2000). Thirst for checking up on things and seek information advanced self-direction as well. Many participants' self-direction and self-esteem were low at the beginning of the studies and strengthening them was an important goal in education:

"That self-confidence, you know, I didn't have it basically at all, so I had to get ahold of myself... and then I got that positive feedback.” (M 6)

Many students remembered how creativity was employed in education; yet, not all understood its meaning or were unable to receive the information. Broadly speaking, it is worth pondering what such qualities or qualifications are that cannot be affected by education and/or that are either already emerged before finding one's way to education or will not even emerge.

Students had learned to use qualifications related to human relationship skills such as interactional skills and social skills the best during practical training (see also Redfem et al., 2002) although plenty of time was invested in both written and verbal communication in education.

"Certainly, we acquired those interactional skills during education and sometimes it seemed even too much. But afterwards you can appreciate many things that you had in education and they have surely been useful along the way” (N 22)

Every interviewee considered the leadership skills that the education provided insignificant or insufficient. Nursing education should include more leadership and administrative studies.

"The work is team work; leadership skills, especially in the evening and night shifts, you have to have managerial responsibility. Studying leadership skills is imperative in nursing education. Administrative studies were superficial at school as a whole.” (N 25)

Nurses and midwives stated that nursing education had increased their qualifications for ethical and responsible operation. The responsibility in nursing was emphasized in the theoretical studies during the education and ethicality and responsibility were manifested concretely in practical training. Confronting morbidity, death, and birth necessitates inner 
professional competence. (Lofmark, Hannersjo, \& Wikblad, 1999.)

"That you lean on that ethics... it encouraged me to grow as a nurse. That responsibility was even overemphasized at some point." (M 6)

Some of the interviewees used visualization practice to go through exceptional situations in nursing (Roberts, While, \& Fitzpatric, 1992). The studying of managing change was considered important which was considered possible only when in actual work.

"You are responsible for so many things in working life. I act for the patient's best and do my work respecting the patient." (N 22)

Every interviewee considered continuous self-development and the things learned through experience important in their professional.

"I think is a package that comes from work experience, age, and one's own experience of life and that either works or not." (M 6)

\subsubsection{Education developed nurses’ outer operational qualifications}

Technological skills, manual skills, tacit know-how, and theoretical knowledge were regarded as outer operational qualifications. Participants had learned the mastery of basic technology in nursing and good ICT skills. It was not considered necessary to learn to use every device and machine in education but they would learn to use them in working life as on-the-job training.

"In working life, the equipment especially in first aid has developed greatly but the education provided good preparedness for the mastery of basic equipment.” (N 22)

Nursing education had provided sufficient manual skills to cope with in working life. They had developed the best during the studies of one's own special field and the period of practical training. Almost every nurse and midwife criticized the overly theoretical start of the first study year during which they did not practice manual skills basically at all making them afraid and insecure of starting their first practical training periods.

"We were the first group at school who did not go through the manual skills at all before going to the first practical training. We went there, you know, to follow [the work]; I felt so insecure. The start of the education was so theory-oriented but it did include the manual skills later on. But indeed, I would have wanted to have manual skill training at the beginning of the education." (N 27)

Nurses had learned tacit know-how from mentors during practical training periods and from colleagues and doctors by learning from model in working life. Professional contacts with colleagues, customers, and interest groups gave both practical information and increased the experience of professional competence. (Edberg, Hallberg, \& Gustafson, 1996.)

"You learn much in practice when the old stagers teach you. In working life, no one teaches you but you have to imitate the older employees.” (N 25)

Nursing education had provided a good and versatile theory base that it was considered as the 
foundation for professional competence. Especially, the final phase of the studies was considered as good when it comes to professional studies. The initial stage of studies was criticized for having excessive amount of general subjects and the students could not integrate them yet in nursing. Similarly, they considered the requirements high and the amount of self-study high. The amount of language studies were regarded as insufficient when thinking of preparedness for working abroad.

"The first year was theoretically rough as you did not have a clue what a nurse's work is." (N 28)

"You have an extensive knowledge base that you have been able to use in practice." (N 22)

\subsection{How Could Education at the University of Applied Sciences be Developed?}

Although nurses and midwives thought of getting a good foundation to their professional competence in nursing education, they had ideas how to develop education. We categorized their perceptions into three groups. The greatest field of development seemed to be to develop the content of the curriculum for nursing education at the university of applied sciences. In addition, improvements in teachers' mentoring and practical training were considered important. These factors are also interconnected.

\subsubsection{By developing the curriculum}

Certain qualifications related to manual skills form a salient part of professional competence and they should be introduced in the curriculum before starting the first practical training. The research participants highlighted that the teaching of manual skills should take place by increasing laboratory education in the first study year. It would lower students' insecurity and possible fear of going to the first practical training periods. During the last study year, students should be able to practice performing some rare treatments but practicing using the devices and machinery happens during practical training and work. Skills tests during practical training periods and especially before graduation were considered significant for evincing manual skills in nursing.

Those who had entered working life considered important that the prioritizing and integration of theoretical knowledge, the development of practical training, and teaching of manual skills should be paid attention to in education at the university of applied sciences. When it comes to teaching the theory, prioritizing is needed, among other things, for decreasing the amount of general subjects and increasing subjects related to nursing especially when studying basic nursing and health care during the first study year (Hayes, 1998). However, the general subjects are important as nurse's work is not just manual performing but one has to be able to fill out various forms, produce written texts such as reports, calculate and so one. Merely, it perhaps is about finding a balance.

Medical treatment education and administrative studies have to be added in education. The amount of language studies, ICT studies, and creativity and interaction studies should be increased as optional studies. Integrating general studies in curricula would decrease the amount of overlapping studies. Furthermore, the curricula should be reconstructed by 
diminishing fragmentariness and designing wider entities. The expertise in nursing changes and therefore, it should be analyzed when doing curriculum work what kind of professional competence and future expertise is needed nursing and how to achieve it though education.

\subsubsection{By developing mentoring}

Concerning teaching arrangements, education should be developed in a direction where pupils have an active, cooperation-based role and where the teacher is a mentor and supporter.

Students need mentoring especially at the beginning and at the final phase of studies (Burgener, 2001). At the beginning, mentoring is connected to making study plans and contentual questions of studying skills and studies. Students need support and feedback from the solutions they have made and their personal strengths (Byrne \& Keefe, 2002). At the end of studies, students have to be prepared for working life and postgraduate studies. In general, teachers' mentoring can strengthen students' qualifications for work and life-management skills both in studies and personal life. (Peluchette \& Jeanquart, 2000.)

“Students should be encouraged in their studies more." (N 23)

"Job seeking skills should be improved during the education.” (N 25)

\subsubsection{By developing practical training}

Professional competence develops during education, practical training, and in working life. Practical instructors and teachers have a significant role as supervisors of students' practical training and as supporters of students' growth and development. The quality of practical training should be increased for example by strengthening cooperation and training students' supervisors (e.g. mentoring education) in order to support students' professional growth (Sheridan \& Dowdney, 1998).

Practical training should be increased in the last year of vocational studies and the practical training periods should be designed into longer and more goal-oriented ones. The participants brought out how using text or practice book during practical training could enhance students' reflection during the development of practical training as well as the integration of theory and practice. Furthermore, they suggested that more practical training could be done abroad in order to make going to work abroad easier.

\section{Conclusions}

According to the results, professional and mental growth had taken place during the whole training as was the appreciation of the occupation. Motivation and self-assurance had increased toward the end of the studies. Also the development of basic professional qualifications was considered significant. The increase in one's own responsibility and getting the occupation and new possibilities through education were seen as remarkable personal qualifications. Students' own appreciation of the occupation is connected to professional growth and development that is important to students' mental development. (Evers et al., 1998; Ruohotie, 1993.) 
Based on the existing literature and the present research, we have developed a model that illustrates the content of the professional competence in nursing field and how it develops (see Figure 1). Many illustrations on work competence consider it as a result of various interconnected factors, such as cognitive skills, personality, work performance that occur and affect in a certain situation and context (see e.g. Kanfer \& Ackerman, 2005) or as a result of several developmental stages (see e.g. Dreyfus \& Dreyfus's model from Novice to Expert, 1986). Our model dissects the development of professional competence from the perspective of education and work experience. It illustrates how professional competence improves and is connected to education and practical experience. Professional competence is regarded as continuously growing, expanding and developing. Furthermore, the steps presented in Figure 1 are partly overlapping as, for example, education takes place all the time from starting education to graduation and in the form of in-service training later on in working life.

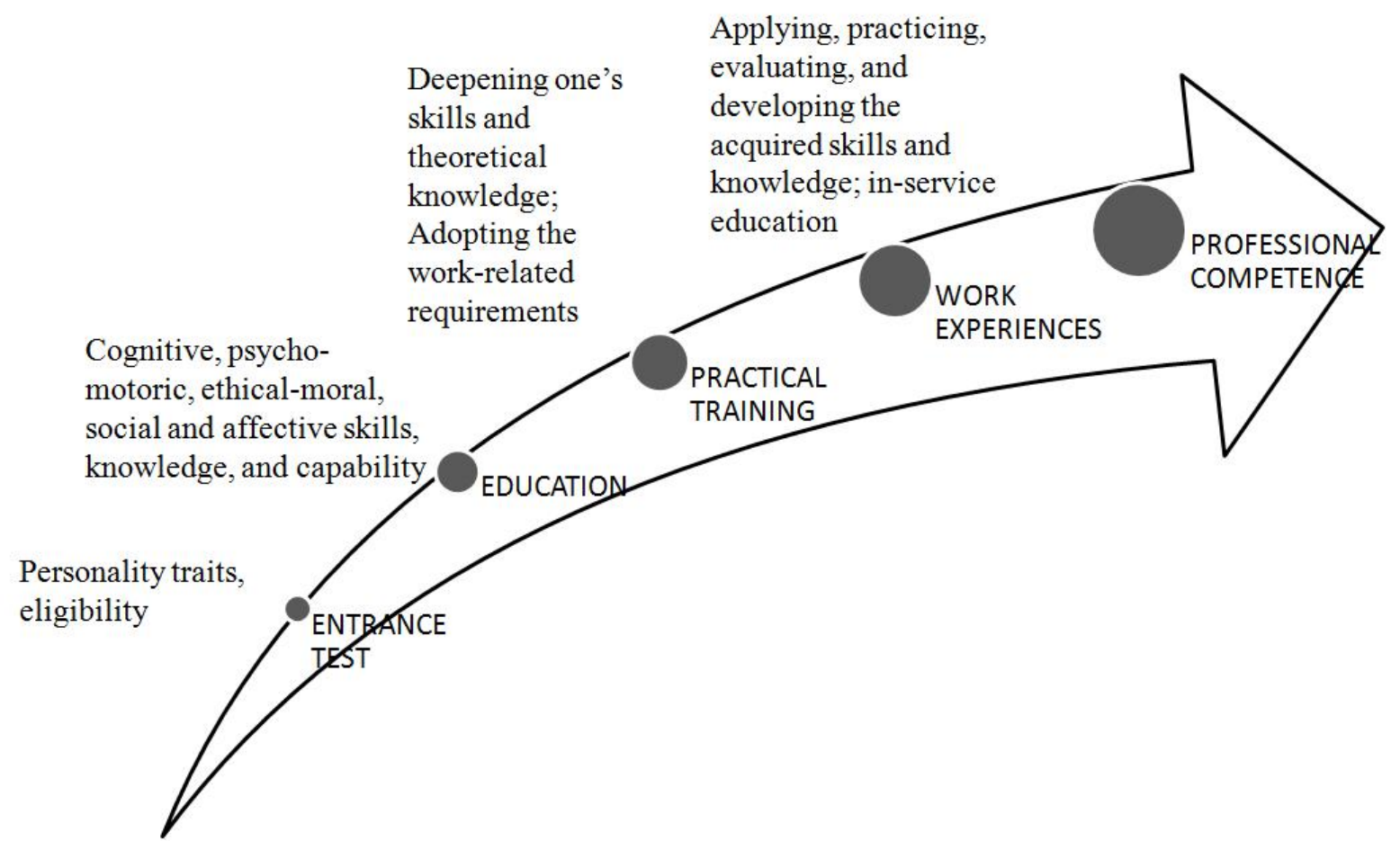

Figure 1. The development of professional competence in nursing

According to Hatcher and Lassiter (2005), competencies are acquired at different rates: Some competencies, such as administrative or supervisory skills, may come slowly and later in professional development. Other more basic competencies, such as timeliness, may be expected and/or required to be substantially attained very early in training. Next, we will dissect each step in the development of nurse's professional competence more closely.

Entrance test can be seen as the first step toward competence in nursing. Those candidates who meet the requirements and are eligible also with regard to their personality traits, competences, beliefs, and attitudes, such as desire to help others, honesty, integrity and 
valuing of ethical behavior, and personal courage, are selected in nursing education.

Through their education, prospective nurses acquire those cognitive, psycho-motor, ethical-moral, social and affective skills, knowledge, and capability that are prerequisites for working as a nurse. Cognitive skills cover skills like problem-solving ability, critical thinking, organized reasoning, intellectual curiosity, and flexibility. Affective skills include skills such as to affect tolerance, understanding of interpersonal conflict, tolerance of ambiguity and uncertainty. Nurse's most important social skills are the ability to listen and be empathic with others, respect for and the interest in others' cultures, experiences, values, points of view, goals, desires, and fears. Ethical and moral skills relate to nurse's knowledge and will to act according to the principles of ethical practice and decision making. Psycho-motor skills refer to the practical skills needed in nursing profession in order to perform treatments and use devices reliably and properly. (see also Hatcher \& Lassiter, 2005.)

Thus, before the beginning of practical training, students should possess and demonstrate a set of basic personal and intellectual skills, attitudes and values, and a core of professional knowledge. This core knowledge and these skills, attitudes and values are baseline competencies, and according to Hatcher and Lassiter (2005), it is inappropriate to start practical training if one has not acquired these skills. However, no one can expect students to be experts when starting practical training as the purpose of it is to train their skills and abilities.

Practical training forms an important part of nurses' education where students deepen their skills and knowledge about nursing profession. During practical training periods, students are supposed to become aware and internalize the demands that relate to nurse's work, for example, the versatile nature of their work, constantly changing situations, responsibility, and cooperation with colleagues and other relevant professionals as well as with patients and their circle of acquaintances. This internalization will become deeper later on at work. Furthermore, the purpose of practical training is to make students more and more familiar with the analytic and action tasks of the field and thus their performance becomes more integrated, flexible, efficient and skilled.

As the results of the research proved, nurse's professional competence is not at its height when graduating but continues its development at work. Through versatile work experience, nurses apply and adapt, practice, assess and develop their acquired knowledge and skills. Their competence becomes wider and profounder along with work experience.

As the nursing field is constantly changing and developing, nurses have to update their professional skills also through in-service training which, for its part, improves competence as well. It worth noticing, that the ability to evaluate and assess one's capacity forms one side of professional competence - and this ability is not obvious but has to be taught (see Saeki et al., 1999) . In addition, Carver and Scheier (2005, p. 543) point out that various situations may occur in working life where an employee has to be able to assess whether the goals are really achievable or whether his/her competence is sufficient and adequate for the demands of the situation in question. Therefore, nurses, as other professionals as well, must develop a proactive attitude which helps them perform well and keep their competence up-to-date (see 
also Uusiautti \& Määttä, 2010; Stoll et al., 2006).

\section{Discussion}

\subsection{The Limitations of the Research}

In this research, the data collected in various phases from different groups and with various methods appeared quite similar and complemented each other. The same main and sub-categories emerged in participants' opinions and thus, the data can be considered reliable. Besides systematic analysis and careful reporting, our aim was to increase reliability by adding excerpts from participants' questionnaire answers and interviews. In phenomenographic research approach, generalization is not the purpose. According to Marton (1988), there is a limited number of ways to understand one phenomenon and that the categories that illustrate the phenomenon are somewhat generalizable into various situations. On the other hand, personal experiences affect perceptions and opinions.

Questionnaires have certain restrictions that have had an influence on this research as well. The results are not objective descriptions about the reality but reveal, at their best, how the participants experience the reality or hope it to be. The nurses may have an insight of an ideal situation which may affect their answers. Theme interview was utilized to complement and picture the results from questionnaires. Yet, the results are not generalizable as such as the participants were carefully selected. However, it was important to study nurses' experiences on their professional competence and with qualitative methods it was possible to reach their perceptions.

\subsection{Implications}

In this research, the nurses assessed their own competence and therefore, the results illustrate their own perceptions on their professional training and competence acquired by education. It would be interesting to compare the competence of those nurses who graduate from universities of applied sciences with the ones who graduate from vocational schools. The first ones blamed their education for being too theoretical while the latter ones have more practice-oriented education. How does professional competence in nursing appear from this point of view?

Furthermore, it would be interesting to ask about nursing students' competence from their supervisors of practical training as well as from head nurses who the newly-graduated nurses work with when entering working life. The role of quality supervision for the development of professional competence is recognized (e.g. Stoltenberg, 2005) and therefore, supervisors' perceptions on students' competence should be studied.

The aim of this article was to contribute a model with which nurse's competence and its development can be assessed both during education and later on in working life. The research results present some crucial points of view on how to develop practical learning and supervision process in nursing education. It is important to discuss and analyze how nursing education prepares for practical work and meets the challenges of working life. Indeed, it has been argued that professional development emphasizes the importance of changing its form 
and traditional approaches to competence are thought to be less responsive to modern working life than the reform approaches (e.g. Birman et al., 2000). Furthermore, the assessment of competence can be made by direct observation of tasks but such observation is acknowledged as problematic as it fails to measure underlying cognitive and affective skills needed for effective practice and to analyze and assess critical thinking skills (Nursing Competence, 2009). Besides qualities that are easily observable, our model pays attention to the last-mentioned areas of professional competence as well.

All in all, the nature of professional competence in nursing field is special. Newly-graduated nurses are qualified to work as nurses but the actual professional competence is still developing. Nurse's profession is such an occupation that is mainly learned in practice and this fact should be realized by nursing educators, employers, and the nursing students as well. Nurse's work requires a specific attitude: nurses have to be willing to enter working life in an open-minded way and learn and practice their skills while working. Yet, they have to remember that the theoretical basis is not any less important. Nursing education provides them with the basic theoretical knowledge that they have to learn to apply in practice in their work. But that is not enough as nurses also have to take care that their proficiency is updated and that their professional competence develops all the while of their careers. In the constantly changing modern working life, this kind of competence is of primary importance.

\section{References}

Aggleton, P., Allen, M., \& Montgomery, S. (1987). Developing a system for the continuous assessment of practical nursing skills. Nurse Education Today, 7, 159-174.

Andre, K., \& Heartfield, M. (2007). Professional portfolios: Evidence of competency for nurses and midwifes. Australia: Elsevier.

Angel, B. F., Duffey, M., \& Belyea, M. (2000). An evidence-based project for evaluating strategies to improve knowledge acquisition and critical-thinking performance in nursing students. Journal of Nursing Education, 39(5), 219-228.

Ashworth, P., \& Morrison, P. (1991). Problems of competence-based nurse education. Nurse Education Today, 11(4), 256-260. http://dx.doi.org/10.1016/0260-6917(91)90087-Q

Baillie, L. (1999). Preparing adult branch student for their management role as staff nurses: An action research project. Journal of Nursing Management, 7, 225-232.

Bartlett, H., Simonite, V., Westcott, E., \& Taylor, H. (2000). A comparison of the nursing competence of graduates and diplomates from UK nursing programmes. Journal of Clinical Nursing, 9(3), 369-379.

Bergström, M. (1997). Työkyky yksilön, pienyrityksen ja yhteiskunnan menestystekijänä [Capability to work as the success factor of an individual, small enterprise, and society] (Work and Human being, Research Report No. 10). Helsinki: Finnish Institute of Occupational Health.

Birman, B. F., Desimone, L., Porter, A. C., \& Garet, M. S. (2000). Designing professional 
development that works. Educational Leadership, 57(8), 28-33.

Brzytwa, E., Copeland, H. L., \& Hewson, M. G. (2000). Managed care education: A needs assessment of employers and educators of nurses. Journal of Nursing Education, 39(5), 197-204.

Burgener, S. C. (2001). Scholarship of Practice for a Practice Profession. Journal of Professional Nursing, 17(1), 46-54.

Butterworth, T. et al. (1997). It is good to talk: an evaluation study of clinical supervision and mentorship in England and Scotland. Manchester: School of Nursing, Midwifery and Health Visiting, University of Manchester.

Byrne, M. W., \& Keefe, M. R. (2002). Building research competence in nursing through mentoring. Journal of Nursing Scholarship, 34(4), 391-396.

Campinha-Bacote, J. (2002). The process of cultural competence in the delivery of healthcare services: a model of care. Journal of Transcultural Nursing, 13, 181-184.

Carnevale, A. P., Gainer, J. L., \& Meltzer, A. S. (1990). Workplace basics: The essential skills employers want. San Francisco, CA: Jossey-Bass.

Carver, C. S., \& Scheier, M. F. (2005). Engagement, disengagement, coping, and catastrophe. In A. J. Elliot, \& C. S. Dweck (Eds.), Handbook of competence and motivation. New York \& London: The Guilford Press. pp. 527-547.

Chiu, C., \& Hong, Y. (2005). Cultural competence: Dynamic processes. In A. Elliot \& C. S. Dweck (Eds.), Handbook of motivation and competence (pp. 489-505). New York, NY: Guilford

Clafin, N. (1997). A practical approach to competency. Journal of Healthcare Quality, 19, 12-18.

Dreher M, \& Macnaughton N. (2002). Cultural competence in nursing: foundation or fallacy? Nursing Outlook., 50(5), 181-186

Drexel, I. (2003). The concept of competence - an instrument of social and political change (Working Paper No. 26). [Online] Available: http://www.ub.uib.no/elpub/rokkan/N/N26-03.pdf (Jun 18, 2011)

Dreyfus, H. L., \& Dreyfus, S. E. (1986). Mind over machine: the power of human intuition and expertise in the age of computer. Oxford: Basil Blackwell.

Dozier, A. M. (1998). Professional standards: linking care, competence and quality. Journal of Nursing Care Quality, 12(4), 22-29.

Edberg, A.-K., Hallberg, I. R., \& Gustafson, L. (1996). Effects of clinical supervision on nurse-patient cooperation quality. Clinical Nursing Research, 5, 127-149.

Ellström, P.-E. (1994). Kompetens, utbilding och lärande i arbetslivet. Problem, begrepp och teoretiska perspektiv [Competence, education and learning in working life]. Stockholm: 
Publica, CE Frizens Ab.

Elmcrona, M., \& Winroth Kileband, M. (1997). Klinisk handledning. Tio sjuksköterskors upplevelser av två års processorienterad handledning. Vård I Norden, 17(3), 4-9.

Eraut, M. R (1998). Concepts of Competence. Journal of Interprofessional Care, 12(2), 127-139.

Eteläpelto, A. (1992). Ammattikorkeakoulun kehittämisen periaatteita [The principles of developing the university of applied sciences]. In J. Ekola (ed.), Johdatusta ammattikorkeakoulupedagogiikkaan [Introduction to the pedagogy of university of applied sciences]. Porvoo: WSOY. pp. 17-42.

Eustace, L.W. (2009). Mandatory continuing education; past, present, and future trends and issues. The Journal of Continuing Education in Nursing, 32, 122-137.

Evers, F. T., Rush, J. C., \& Berdrow, I. (1998). The bases of competence: skills for lifelong learning and employability. San Francisco, CA: Jossey-Bass.

Evers, F. T., \& Rush, J.C. (1996). The bases of competence: skill development during the transition from university to work. Management Learning, 27(3), 275-299.

Giger, J. et al. (2007). American academy of nursing expert panel report: developing cultural competence to eliminate health disparities in ethnic minorities and other vulnerable populations. Journal of Transcultural Nursing, 18(2), 95-102. http://dx.doi.org/10.1177/1043659606298618

Girot, E. A. (2000) Assessment of graduates and diplomats in practice in the UK - are we measuring the same level of competence? Journal of Clinical Nursing, 9(3), 330-336.

Gonzi, A. (1994). Competency based assessment in the professions in Australia. Assessment in Education, 1, 27-44.

Hayes, E. F. (1998). Mentoring and nurse practitioner student self-efficacy. Western Journal of Nursing Research, 20(5), 521-535.

Hatcher, R. L., \& Lassiter, K. D. (2005). Report on Practicum Competencies. The Association of Directors of Psychology Training Clinics (ADPTC) Practicum Competencies Workgroup. [Online] Available:: http://www.adptc.org/public_files/ (Jul 5, 2011).

Jaroma, A. (2000). Koulutus ja tuleva toiminta hoitotyössä [Education and future work in nursing field]. Kuopio: University of Kuopio.

Järvinen, A. (1985). Lääketieteen opiskelijoiden tieteellisiä ja ammatillisia käsityksiä koskeva seurantatutkimus [Follow-up study on medicine students' scientific and professional perceptions] (Acta Universitatis Tamperensis A 197). Tampere: University of Tampere.

Kanfer, R., \& Ackerman, P. L. (2005). Work competence: A person-oriented perspective. In A. J. Elliot, \& C. S. Dweck (Eds.), Handbook of competence and motivation. New York \& London: The Guilford Press. pp. 336-353. 
Katz, R. (1998). Managing the mandatories: Back to basics. In K. J. Kelly-Thomas (ed.), Clinical and nursing staff development. New York, NY: Lippincott. pp. 146-160.

Kautto-Koivula, K. (1993). A degree-oriented professional adult education in the work environment (Acta Universitatis Tamperensis A390). Tampere: University of Tampere.

Keen, K. (1991). Competence - What is it and how can it be development. Proceedings of Ette Conference. pp. 61-71.

Khomeiran, R.T., Yekta, Z.P., Kiger, A.M., \& Ahmadi, F. (2006). Professional competence: factors described by nurses as influencing their development. International Nursing Review, 53(1), 66-72.

Lofmark, A., Hannersjo, S., \& Wikbland, K. (1999). A summative evaluation of clinical competence: students' and nurses' perceptions of inpatients' individual and emotional needs. $\begin{array}{llll}\text { Journal of } \quad \text { Advanced } & \text { Nursing, } & \text { 29, }\end{array}$ http://dx.doi.org/10.1046/j.1365-2648.199900976x

Lorenz, R. A. (1986). Training health professionals to improve the effectiveness of patient education programs. Diabetes Educator, 12, 4-7.

Lorenz, R. A., \& Pichert, J. W. (1989). Evaluation of education program development: Illustration of the research and development cycle. Diabetes Educator, 12, 204-209.

Lundblad, B., Byrne, M. W., \& Hellström, A.-L. (2001). Continuing nursing care needs of children at time of discharge from one regional medical center in Sweden. Journal of Pediatric Nursing, 16(1), 73-78.

Marton, F. (1994). Phenomenography. Göteborg: Göteborg University. Retrieved from: http://www.ped.gu.se/biorn/phgraph/civil/main/lres.appr.html (21 June 2011)

Marton, F. \& Booth, S. (1997). Learning and awareness. Mahwah, NJ: Lawrence Erlbaum Associates.

Medoff-Cooper B, \& Dekeyser F. (1998). Developing a research mentoring partnership in Israel. Journal of Obstetric, Gynecologic, and Neonatal Nursing, 27(2), 197-202.

Munch, B., \& Jakobsen, A. (2005). The concept of competence in engineering practice. Engineering and Product Design Education Conference. 15-16th September 2005, Napier University, Edinburgh, UK.

Ngin, P., Simms, L. M., \& Erbin-Roesemann, M. (1993). Work excitement among computer users in nursing. Computers in Nursing, 11, 127-133.

Nursing competence: what are we assessing and how should it be measured? (2009). Policy+, 18. London: King's College. [Online] Available: http://www.kcl.ac.uk/content/1/c6/05/68/69/PolicyIssue18.pdf (Jul 5, 2011.)

Peluchette, J. V., \& Jeanquart S. (2000). Professionals' use of different sources at various career stages: implications for career success. Journal of Social Psychology, 140(5), 549-564.

Raven, J. (1995). The universities, the development of competence and public policy. 
Capability, 1(3), 3-6.

Redfem, S., et al. (2002). Assessing competence to practice in nursing: a review of the literature. Research Papers in Education, 17, 51-77. http://dx.doi.org/10.1080/02671520110058714 .

Roberts, J. D., While, E., \& Fitzpatrick, J. M. (1992). Simulation current status in nurse education. Nurse Education Today, 12, 405-415.

Ruohotie, P. (1993). Ammatillinen kasvu työelämässä [Professional growth in working life]. Hämeenlinna: University of Tampere.

Saeki, K., Kawaharada, M., Hayama, M., \& Igarashi, M. (1999). Development of professional competence in public health nurses. Japanese Journal of Public Health, 46(9), 779-789.

Sheridan, D. R., \& Downdney, D. L. (1998). Mentoring new nurse authors. Nurse Author Educator, 8(2), 4-8.

Sinclair, M., \& Gardner, J. (1999). Planning for information technology key skills in nurse education. Journal of Advanced Nursing, 30(6), 1441-1450.

Stetson, B. A., Pichert, J. W., Roach, R. R., Lorenz, R. A., Boswell. E. J., \& Schlundt, D. G. (1992). Registered dietitians' teaching and adherence promotion skills during routine patient education. Patient Education \& Counselling, 19, 273-280.

Stoll, L., Bolam, R., McMahon, A., Wallace, M., \& Thomas, S. (2006). Professional learning communities: A review of the literature. Journal of Educational Change, 7, 221-258.

Stoltenberg, C. D. (2005). Enhancing professional competence through developmental approaches to supervision. American Psychologist, 6, 857-864.

Streumer, C. W. (1993). Qualification, competence and certification in the modular-vocational education in the Netherland. In R. Mäkinen, \& M. Taalas (Eds.), Producing and certifying vocational qualifications. Jyväskylä: University of Jyväskylä. pp. 67-69.

Syrjälä, L., Ahonen, S, Syrjäläinen, E., \& Saari, S. (1994). Laadullisen tutkimuksen työtapoja [Working methods of qualitative research]. Helsinki: Kirjayhtymä.

Tashakkori, A., \& Teddlie, C. (2003). The past and future of mixed methods research: From data triangulation to mixed model designs. In A. Tashakkori, \& C. Teddlie (Eds.), Handbook of mixed methods in social \& behavioral research. Thousand Oaks, CA: Sage. pp. 671-701.

Thompson, C., \& Rebeschi, L. M. (1999). Critical thinking skills of baccalaureate nursing students at program entry and exit. Nursing and Health Care Perspectives, 20(5), 248-252.

Tuomi, J., \& Sarajärvi, A. (2002). Laadullinen tutkimus ja sisällönanalyysi [Qualitative research and content analysis]. Jyväskylä: Gummerus.

Tzeng H. (2004). Nurses’ self-assessment of their nursing competencies, job demands and job 
performance in the Taiwan hospital system. International Journal of Nursing Studies, 44, 487-496.

Uusiautti, S., \& Määttä, K. (2010). What kinds of employees become awarded as Employees of the Year in Finland? Enterprise and Work Innovation Studies, 6, 53-73. Retrieved from: http://hdl.handle.net/10362/5725

Uusiautti, S., \& Määttä, K. (2011, accepted). Process of Becoming a Top Worker. International Education Studies.

Watkins, M. J. (2000). Competency for nursing practice. Journal of Clinical Nursing, 9, 338-346. http://dx.doi.org/10.1046/j.1365-2702.2000.00402.x

Watson, R., Stimpson, A., Topping, A., \& Porock, D. (2002). Clinical competence assessment in nursing: a systematic review of the literature. Journal of Advanced Nursing, 39(5), 421-431.

Weidner, F. (1995). Professionelle Pflegepraxis und Gesundheitsförderung. Eine empirische Untersuchung über Voraussetzungen und Perspektiven des beruflichen Handelns in der Krankenpflege. Frankfurt: Mabuse.

Westerholm, H. (2007). Tutkimusmatka pienyrittäjän työvalmiuksien ytimeen. Kirjallisuuteen ja DACUM-analyysiin perustuva kartoitus. [A Journey into the Core of the Occupational Competence and Attitudes of Small Business Entrepreneurs. A Study Based on a Review of Literatur and A Dacum analysis] (Jyväskylä Studies in Business Economics No. 55). Jyväskylä: University of Jyväskylä.

While, A., (1994). Competence versus performance: which is more important? Journal of Advanced Nursing, 20(3), 525-531.

Wolgin, F. (1998). Competence assessment system and measurement strategies. In K. J. Kelly-Thomas (Ed.), Clinical and nursing staff development. New York, NY: Lippincott. pp. 100-120.

Zhang, Z. X., Luk, W., Authur, D., \& Wong, T. (2001). Nursing competencies: personal characteristics contributing to effective nursing performance. Journal of Advanced Nursing, 33(4), 467-474.

\section{Copyright Disclaimer}

Copyright reserved by the author(s).

This article is an open-access article distributed under the terms and conditions of the Creative Commons Attribution license (http://creativecommons.org/licenses/by/3.0/). 